TITLE:

$<$ Case Report>Isolated Dislocation of the Carpal Scaphoid : A Case Report

$\operatorname{AUTHOR}(\mathrm{S}):$

YASUDA, TADASHI

CITATION:

YASUDA, TADASHI. <Case Report>Isolated Dislocation of the Carpal Scaphoid: A Case Report. 日本外科宝函 1997, 66(2): 59-65

ISSUE DATE:

1997-05-01

URL:

http://hdl.handle.net/2433/202867

RIGHT: 


\title{
Isolated Dislocation of the Carpal Scaphoid: A Case Report
}

\author{
TADASHI YASUDA
}

\author{
Department of Orthopedic Surgery Moriyama City Hospital
}

Received for Publication, Feb. 25., 1997

An isolated dislocation of the carpal scaphoid is rare, and a significant radiological finding that distinguishes dislocation of the scaphoid from perilunate dislocation is the volar and radial displacement of the proximal pole of the scaphoid from the scaphoid fossa of the radius. In review of the literature, the standard methods of treatment have not been established. In some reports, dislocation of the scaphoid has been successfully treated with cast immobilization after closed reduction ${ }^{1-5)}$. Other reports have advocated open reduction and internal fixation as treatment for dislocation of the scaphoid $^{5-13)}$. In this paper, we present a case in which open reduction with internal fixation was required after failed closed reduction. The mechanism of dislocation of the scaphoid and a treatment approach are also discussed.

\section{Case Report}

A fifty-seven-year-old man sustained an injury of the left, non-dominant wrist in a motor-vehicle collision while driving the vehicle. In the emergency room on the day of the injury, left wrist was painfully swollen in a position of ulnar deviation. There were tenderness and a palpable prominence over the radial aspect of left carpus. The neurovascular status was found to be normal. Radiographs revealed a radiovolar dislocation of left scaphoid (Figs. 1-A and 1-B). In addition, the patient sustained a fracture of right acetabulum.

Under local anesthesia, reduction of the proximal pole of the scaphoid to the scaphoid fossa of the radius was attempted with manual pressure over the palpable osseous prominence under longitudinal traction in a position of ulnar deviation. However, subsequent review of radiographs demonstrated a scapholunate diastasis. Next day after the injury, attempts at closed reduction under regional anesthesia with fluoroscopic control failed because of a persistent scapholunate diastasis (Fig. 2-A). Fluoroscopic examination revealed a lack of synchronous motion between the scapoid and the lunate (Fig. 2-B). Open reduction with pinning was performed through a volar approach. Notable intraoperative findings included complete tears of the volar radioscaphocapitate ligament and of the scapholunate interosseous ligament which was invaginated in the scapholunate interval to block reduction. After extrication of the invaginated ligament, the diastasis was reduced. Two smooth Kirscher wires were drilled; one between the scaphoid and the lunate and one between the scaphoid and the hamate through the capitate (Figs. 3-A and 3-B).

Postoperatively, an above-elbow thumb-spica cast was applied for four weeks. A below-the-

Present address: Department of Orthopaedic Surgery Moriyama City Hospital 4-14-1 Moriyama, Moriyama City Shiga 524, Japan

索引用語: 舟状骨, 脱臼, 舟状骨脱臼, 手術

Key words: carpal scaphoid, dislocation, scaphoid dislocation, operation 
elbow thumb-spica cast was worn for another four weeks. The pins were removed at eight weeks, and therapy was begun to restore motion and strength. At the latest follow-up, two years postoperatively, the patient was pain-free and had full motion of the wrist. There was no clinical or radiological evidence of carpal instability, avascular necrosis, or osteoarthrosis (Figs. 4-A and 4-B).
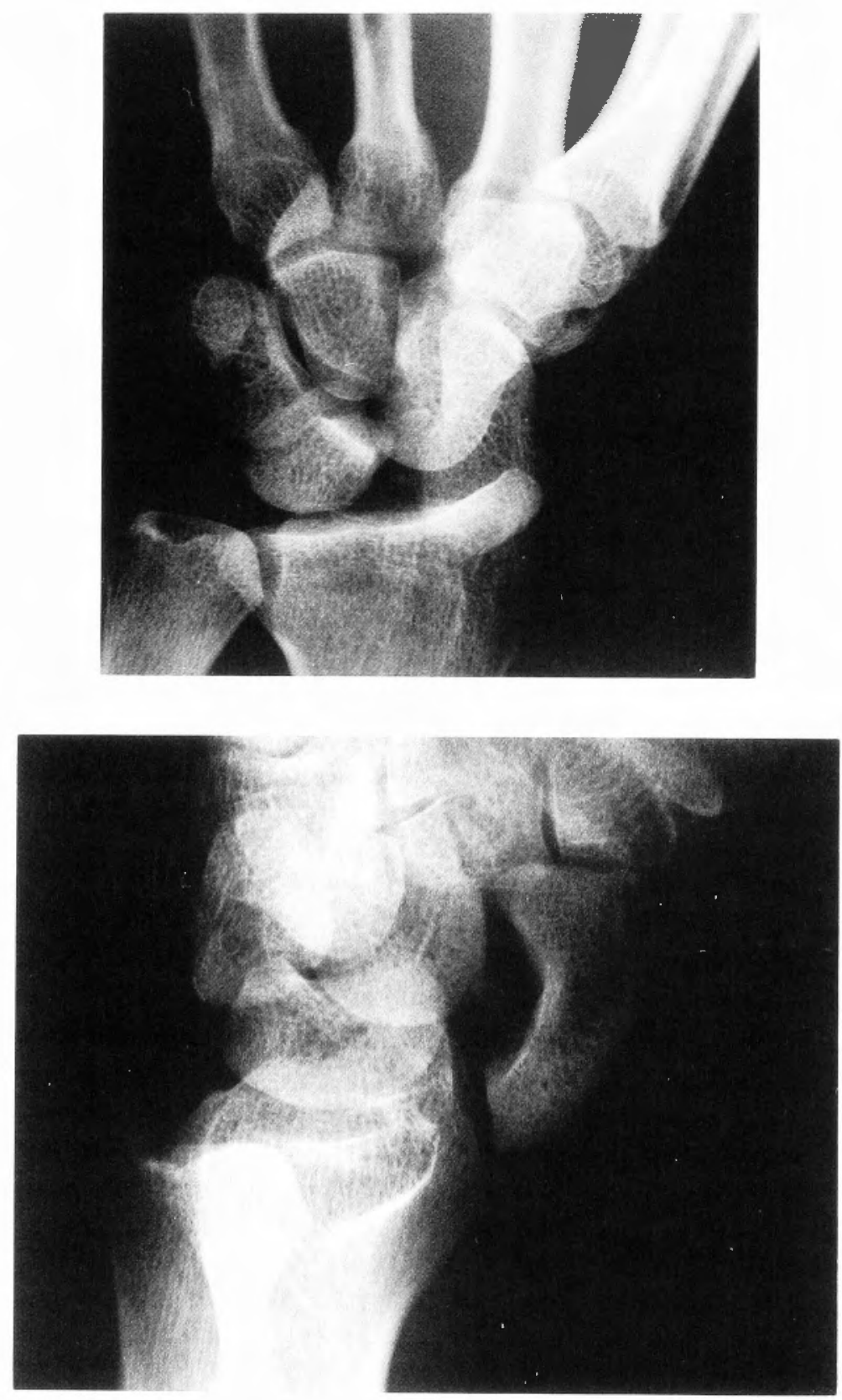

Figs. 1-A and 1-B Anteroposterior (A) and oblique (B) radiographs showing acute radiovolar dislocation of the scaphoid. 


\section{Discussion}

Isolated dislocation of the carpal scaphoid was rarely encountered. To our knowledge, thirteen reports of seventeen patients have described radiovolar dislocation of the scaphoid in the English-language literature ${ }^{1,3-10,12-15}$. The mechanism of dislocation of the scaphoid is uncertain. From studies of perilunate dislocation and fracture of the scaphoid, extension of the wrist, intercarpal supination and ulnar deviation have been suggested to be involved in the dislocation ${ }^{16)}$. In the current case, together with the previously reported $\operatorname{cases}^{13)}$, drivers involved in motor-vehicle accidents sustained dislocation of the scaphoid. This indicates that the transmission of force to the wrist through the steering wheel or shift lever may predispose to this dislocation ${ }^{13)}$.

It is important to recognize dislocation of the scaphoid as the result from periscaphoid ligament damage. The stabilizing ligaments of the proximal pole and the waist of the scaphoid are the radioscaphocatpitate ligament, the scaphlunate interosseous ligament, and the long radiolunate ligament. Besides those ligaments, the scaphotrapezial ligament and the scaphocapitate ligament, which are considered important elements of stable carpal relationships, stabilize the distal pole from its volar surface ${ }^{17,18)}$. The radioscapholunate ligament has been proved to act only as a neurovascular conduit without substantial stabilizing function ${ }^{19)}$. The radioscaphocapitate ligament plays a role as a fulcrum in motion of the scaphoid in the sagittal plane. Injury of the scaphotrapezial and scaphocapitate ligaments combined with injury of the scapholunate interosseous ligament probably causes scapholunate instability after perilunate dissociation. Furthermore, the scaphotrapezial and scaphocapitate ligaments have been suggested to function as a pivot for dislocation of the scaphoid ${ }^{18,20)}$. On the basis of the arthroscopic findings in dislocation of the scaphoid, SzaBo et al have ad-

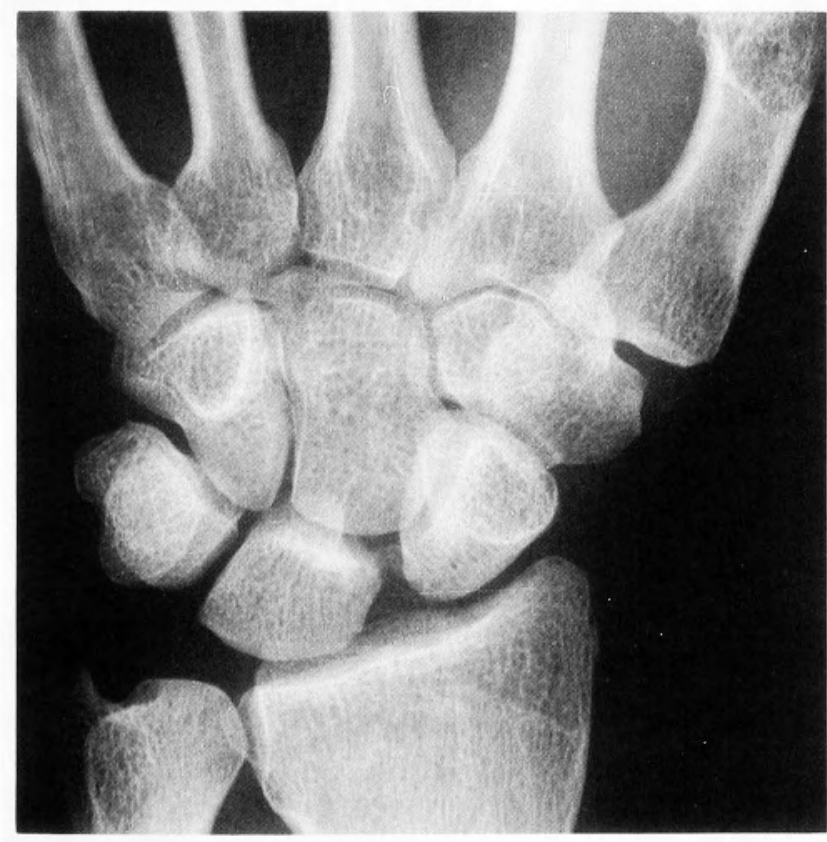

Fig. 2-A Anteroposterior radiograph in a neutral position of the wrist taken after closed reduction, demonstrating a persistent scapholunate diastasis with avulsed fragments. 
vocated that periscaphoid ligament failure initiates in the radiovolar aspect of the proximal pole with failure of the radioscaphocapitate and scapholunate interosseous ligaments in association with dislocation of the proximal pole of the scaphoid. Thereafter, the ligament failure progresses to the long radiolunate ligament, and ends with the scaphotrapezial ligament in association with dislocation of the distal pole of the scaphoid ${ }^{13)}$. Arthroscopy will provide useful information about ligamentous injuries and become an essential tool in case of scaphoid dislocation ${ }^{13)}$.

In regard to treatment of dislocation of the scaphoid, successful management with immobilization after closed reduction has been reported ${ }^{1,3-10,12)}$. However, while obtained initial anatomical reduction, closed reduction of perilunate dislocation tends to result in reduction ${ }^{21)}$. Similar to perilunate dislocation, association of dislocation of the scaphoid with periscaphoid ligamentous injuries could lead to failed closed reduction or redislocation after initial closed reduction ${ }^{5,13,14)}$. Therefore, percutaneous pinning is recommended to maintain reduction in a cast. Immobilization in a cast is necessary to supplement the percutaneous fixation, although the selection of above-the-elbow or below-the-elbow cast and duration of immunobilization are still controversial ${ }^{13)}$. Presence of a residual scapholunate diastasis after initial closed reduction requires fluoscopic examination. If fluoroscopy demonstrates synchronous motion between the scaphoid and the lunate, indicating incomplete tear of the scapholunate interosseous ligament, arthroscopy may be helpful for evaluation and removal of possible soft-tissue interposition and percutanous pinning instead of open reduction 13). In contrast, when there is dyssynchronous motion between the scaphoid and the lunate as in the current case (Fig. 2-B), indicative of complete tear of the scapholunate interosseous ligament, open reduction with pinning is the option for the treatment ${ }^{13)}$. Dorsal approach is considered feasible to

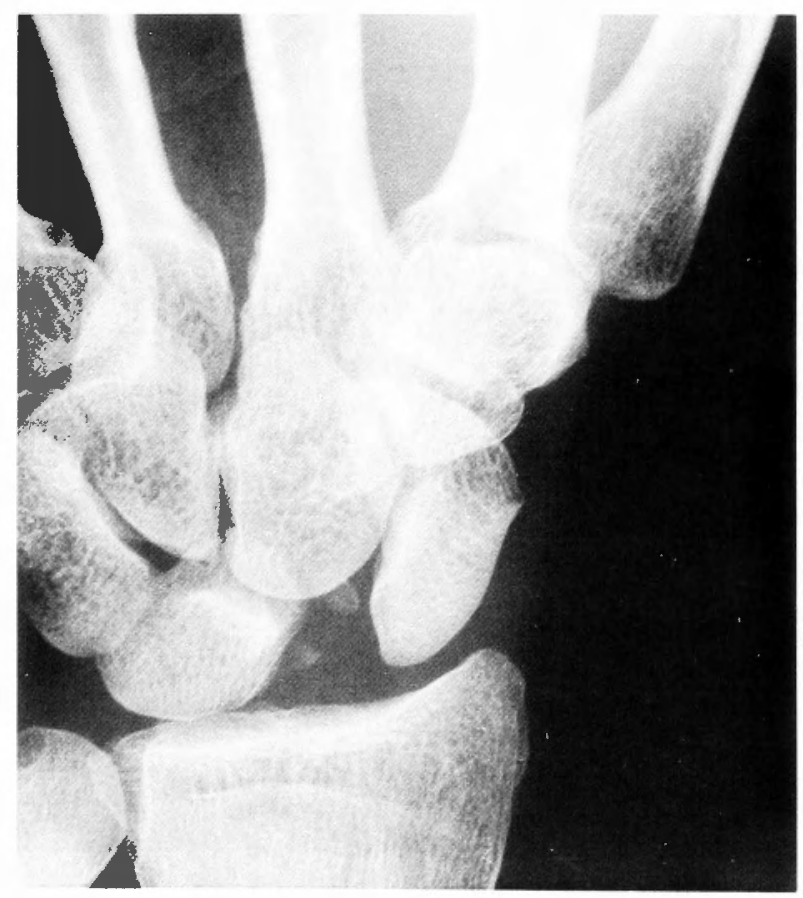

Fig. 2-B Anteroposterior radiograph in a position of wrist extension, showing widening of the scapholunate diastasis. 
repair the scapholunate interosseous ligament, if necessary. In the current case, operation was per formed through volar approach to avoid damaging the dorsal blood supply to the scaphoid. Open reduction and internal fixation is also indicated at the failure of closed reduction of the proximal pole of the scaphoid due to the lack of an intact hinge at the distal pole of the scaphoid. In such dislocations, careful long-term follow-up is mandatory because severe stripping of ligamentous attachment from the scaphoid may disturb blood supply and cause avascular necrosis despite anatomical reduction ${ }^{13)}$.
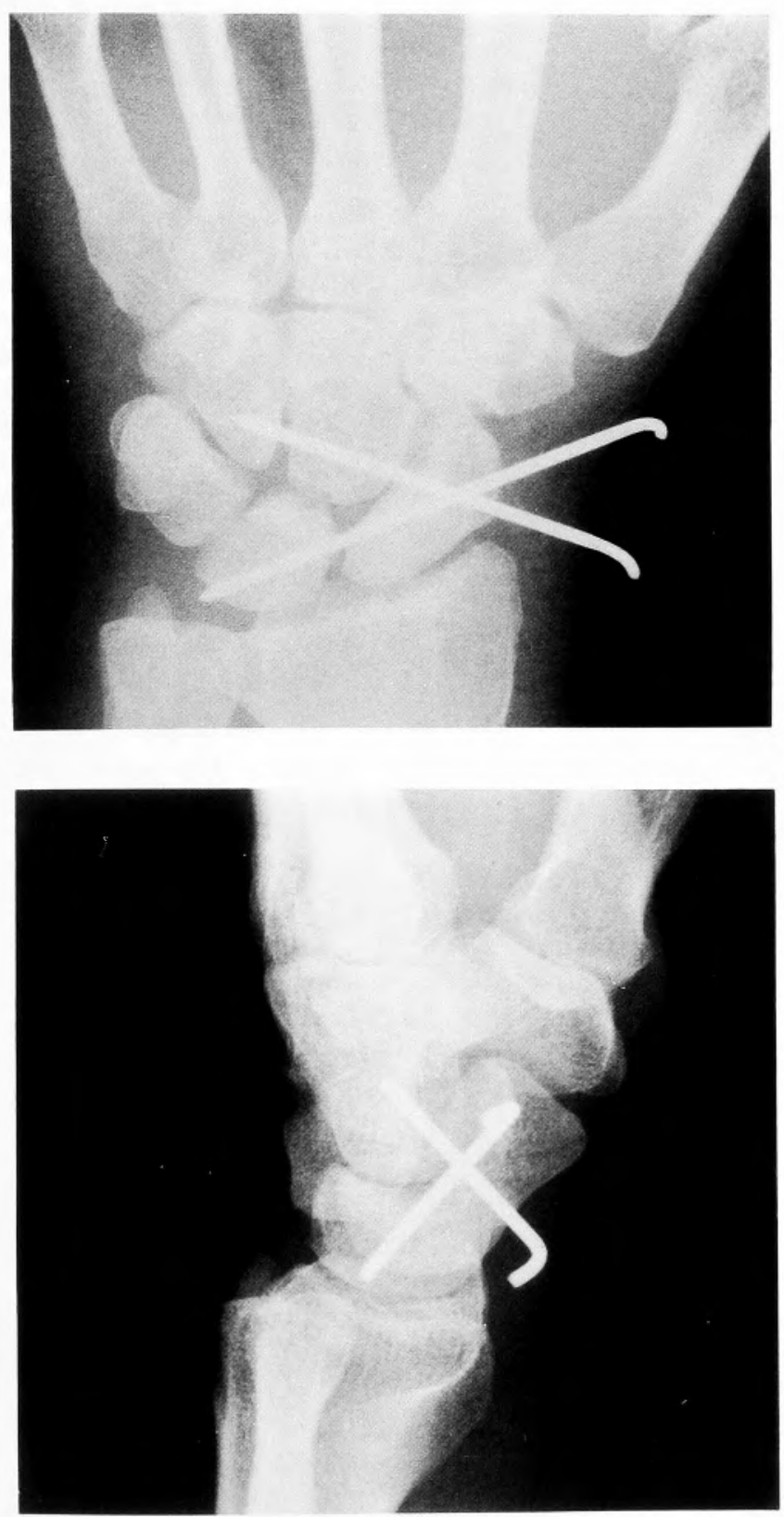

Figs. 3-A and 3-B Anteroposterior (A) and lateral (B) radiographs made after open reduction and internal fixation. 


\section{References}

1) Amamilo SC, Uppal R, Samuel AW: Isolated dislocation of carpal scaphoid. J Hand Surg 10-B: 385-388, 1985.

2) Inoue $\mathrm{G}$, Maeda $\mathrm{N}$ : Isolated dorsal dislocation of the scaphoid. J Hand Surg 15-B: 368-369, 1990.

3) Maki NJ, Chuinard RG, D'Ambrosia R: Isolated, complete radial dislocation of the scaphoid. A case report and review of the literature. J Bone Joint Surg 64-A: 615-616, 1982.

4) Schlossbach T: Dislocation of the carpal navicular bone not associated with fracture. J Med Soc New Jersey 51 :
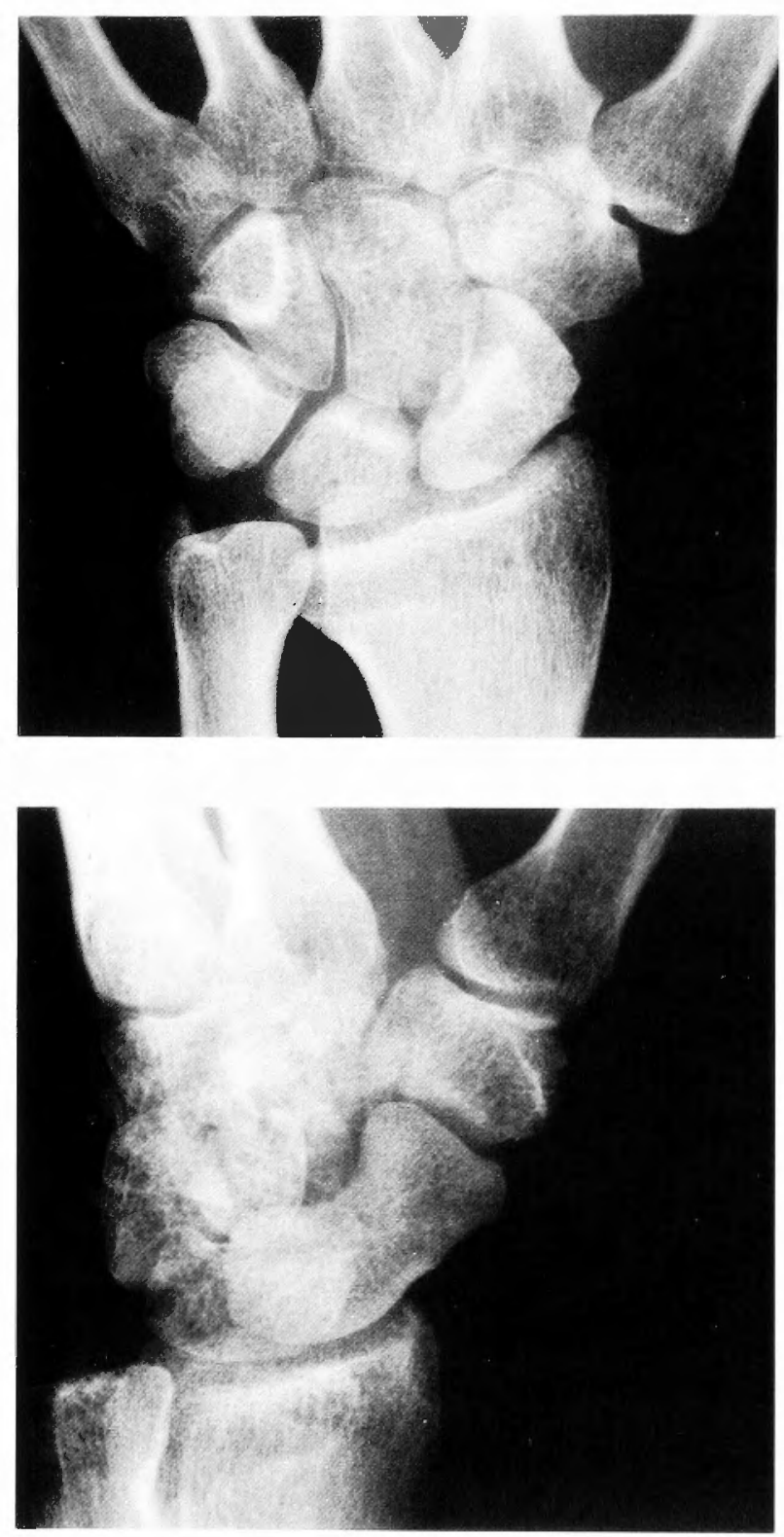

Figs. 4-A and 4-B Anteroposterior (A) and oblique (B) radiographs taken two years postoperatively. 
$553-534,1954$.

5) Thomas HO: Isolated dislocation of the carpal scaphoid. Acta Orthop Scandianvica 48: 369-372, 1977.

6) Buzby BF: Isolated radial dislocation of carpal scaphoid. Ann Surg 100: 553-555, 1934.

7) Connell MC, Dyson RP: Dislocation of the carpal scaphoid. Report of a case. J Bone Joint Surg 37-B: 252-253, 1995.

8) Higgs SL: Two cases of dislocation of carpal scaphoid. Proc Roy Soc Med 23: 1337-1339, 1930.

9) Kuth JR: Isolated dislocation of the carpal navicular. A case report. J Bone Joint Surg 21: 479-483, 1939.

10) Murakami Y: Dislocation of the carpal scaphoid. Hand 9: 79-81, 1977.

11) Parkes JC, Stovell PB: Dislocation of the carpal scaphoid: a report of two cases. J Trauma 13: 384-388, 1973.

12) Ritchie DA, Gibson PH: Isolated dislocation of the scaphoid. Injury 19: 405-406, 1988.

13) Szabo RM, Newland CC, Johnson PG, et al: Spectrum of injury and treatment options for isolated dislocation of the scaphoid. A report of three cases. J Bone Joint Surg 77-A: 608-615, 1995.

14) McNamara MG, Corley FG: Dislocation of the carpal scaphoid: an 8-year follow-up. J Hand Surg 17-A: 496-498, 1992.

15) Walker GBW: Dislocation of the carpal scaphoid reduced by open operation. British J Surg 30:380-381, 1943.

16) Mayfield JK, Johnson RP, Kilcoyne RK: Carpal dislocations: pathomechanics and progressive perilunar instability. J Hand Surg 5: 226-241, 1980.

17) Blevens AD, Light TR, Jablonsky WS, et al: Radiocarpal articular contact characteristic with scaphoid instability. J Hand Surg 14-A: 781-790, 1989.

18) Drewniany JJ, Palmer AK, Flatt AE: The scaphotrapezial ligament complex: an anatomic and biomechanical study. J Hand Surg 10-A: 492-498, 1985.

19) Berger RA, Kauer JM, Landsmeer JM: Radioscapholunate ligament: a gross anatomic and histologic study of fetal and aduult wrists. J Hand Surg 16-A: 350-355, 1991.

20) Drewniany JJ, Palmer AK: Isolated, complete radial dislocation of the scaphoid [letter]. J Bone Joint Surg 65-A: 871-872, 1983.

21) Adkison JW, Chapman MW: Treatment of acute lunate and perilunate dislocations. Clin Orthop 164: 199-207, 1982.

和文抄録

\title{
手舟状骨単独脱臼の 1 例
}

\author{
守山市民病院 整形外科 \\ 安田義
}

徒手整復はできず観血的整復が必要であった手舟状 骨単独脱扫の 1 例を経験したので報告する。

【症例】57歳, 男性. 車の運転中衝突事故で左手舟状 骨に脱臼をきたした。徒手整復を試みるも損傷勒帯の 介在による舟状骨月状骨離開が残存したため, 観血的 火整復固定した，術後経過は良好で，不安定性，骨壊 死为認めない。
手舟状骨単独脱臼は稀であり，未だ確立した治寮法 はない，徒手整復に成功した報告もあるが，今までの 報告例と月状骨周囲脱目の治療成績から考えると pinning を併用することが望ましい，再脱目する場合若 しくは本例のよらに舟状骨月状骨離開が残存する場合 には観血的手術が必要となる。舟状骨脱体に伴う勒帯 損傷の評価に関節鏡が今後有用になると思われる。 